\title{
Protective effect of quercetin on acute lung injury in rats with sepsis and its influence on ICAM-1 and MIP-2 expression
}

\author{
L. Meng, Z. Lv, Z.Z. Yu, D. Xu and X. Yan \\ Department of Anesthesiology, Wuhan Union Hospital of China, Wuhan, China \\ Corresponding author: L. Meng \\ E-mail: leimeng989@126.com
}

Genet. Mol. Res. 15 (3): gmr.15037265

Received July 21, 2015

Accepted October 30, 2015

Published July 29, 2016

DOI http://dx.doi.org/10.4238/gmr.15037265

Copyright $(C 2016$ The Authors. This is an open-access article distributed under the terms of the Creative Commons Attribution ShareAlike (CC BY-SA) 4.0 License.

\begin{abstract}
This study aimed to explore the protective effect of quercetin on acute lung injury (ALI) in rats with sepsis and the related mechanism. Rats were administered different doses of quercetin intraperitoneally, and blood samples and lung tissue were collected at $24 \mathrm{~h}$ after treatment. Arterial blood gases, lung water content, protein content, and cell counts in bronchoalveolar lavage fluid (BALF) were measured. Morphological changes in lung tissue pathology were observed under a light microscope. Serum intercellular adhesion molecule (ICAM)-1 and macrophage inflammatory protein 2 (MIP2) levels were detected and ICAM-1 and MIP-2 mRNA expression in lung tissue was determined. Compared with that in the control model group, arterial blood gases, lung water content, protein content, and cell counts in BALF improved in the high- and low-dose quercetin groups ( $\mathrm{P}<0.05)$, with maximal improvement observed for the highdose quercetin $(\mathrm{P}<0.05)$. Lesions on the lungs improved in the high-
\end{abstract}


and low-dose quercetin groups than those in the control model group, and the high-dose quercetin group showed better improvement than the low-dose group $(\mathrm{P}<0.05)$. Compared with that in the sham-operated group, both serum and lung tissue ICAM-1 and MIP-2 expression increased significantly in the model group $(\mathrm{P}<0.05)$. The quercetin groups presented lower ICAM-1 and MIP-2 expression than the control model group, with the lowest expression observed in the high-dose group $(\mathrm{P}<0.05)$. Quercetin may protect against ALI in rats with sepsis by inhibiting ICAM-1 and MIP-2 expression.

Key words: Quercetin; Sepsis; Acute lung injury; ICAM-1; MIP-2

\section{INTRODUCTION}

Sepsis, also known as systemic inflammatory response syndrome, is caused by a toxin, which is produced by pathogenic bacteria or conditional pathogenic bacteria in blood circulation (Vincent, 2014; Ali et al., 2015; Krajcinovic et al., 2015; Nagarjuna et al., 2015). Sepsis may cause acute lung injury (ALI) (Odani et al., 2015; Xue et al., 2015). ALI causes pulmonary vascular cells to produce various cytokines, chemokines, adhesion molecules, and other inflammatory mediators, which may destroy the integrity of the pulmonary vascular endothelial cells and lead to an increase in the permeability of lung capillaries. As a result, patients become prone to pulmonary edema, which may cause acute respiratory distress syndrome and multiple organ failure. These factors contribute to the high fatality rate associated with ALI (Berthiaume et al., 2002). Currently, the main treatment method for sepsis-induced ALI is administration of antibiotics and a potent vasoactive agent, but their effectiveness is limited. Quercetin is effective for eliminating phlegm, relieving coughing, and as an antiasthma agent. It can also lower blood pressure, improve blood capillary resistance, reduce capillary fragility, reduce blood fat, expand the coronary artery, and increase coronary blood flow. Clinically, quercetin is used for treating chronic bronchitis, coronary heart disease, and hypertension. In addition, quercetin may protect against ALI caused by sepsis (Bai et al., 2014). However, the mechanism is is yet to be determined. The study aimed to investigate the mechanism of the protective role of quercetin against sepsis-induced ALI by using rat models. We used the cecal ligation and puncture (CLP) method to construct an ALI rat model and studied the effect of quercetin administration on arterial blood gases, lung water content, protein content, and cell count in bronchoalveolar lavage fluid (BALF). We further observed the pathological morphological changes in the lung tissue and determined intercellular adhesion molecule (ICAM)-1 and macrophage inflammatory protein 2 (MIP-2) levels in the serum and lung tissue.

\section{MATERIAL AND METHODS}

\section{Animals}

Healthy adult male Wistar rats (40) (body weight 180-230 g) were purchased from Beijing Vital River Experimental Animal Technical Co., Ltd. The Wistar rats were raised in a 12-h day-night temperature-controlled room. The rats were randomly divided into 4 groups of

Genetics and Molecular Research 15 (3): gmr.15037265 
equal size: control group (S), model group (M), and quercetin groups $\mathrm{L}$ and $\mathrm{H}$ groups (30 and $50 \mathrm{mg} / \mathrm{kg}$, respectively).

Rats were used for all experiments, and all procedures were approved by the Animal Ethics Committee of Wuhan Union Hospital of China.

\section{Modeling and treatment}

The CLP method was used to create the ALI-sepsis rat model (Tsushima et al., 2009). The rats were anesthetized using $6 \%$ chloral hydrate $(400 \mathrm{mg} / \mathrm{kg})$. The rats in the sham operation group only underwent laparotomy. Different doses of quercetin were intraperitoneally injected into the rats at 6 and $18 \mathrm{~h}$ after surgery (Costa et al., 2015). The rats in groups $\mathrm{M}$ and $\mathrm{S}$ received equal amounts of normal saline.

\section{Specimen collection}

Blood samples and lung tissue were collected from the rats $24 \mathrm{~h}$ after treatment. The blood was extracted from the aorta abdominalis after anesthesia, and the lung tissue was obtained from the thoracic cavity.

\section{$\mathrm{PaO}_{2}$ and $\mathrm{PaO}_{2} / \mathrm{FiO}_{2}$ value detection}

$\mathrm{PaO}_{2}$ and $\mathrm{PaO}_{2} / \mathrm{FiO}_{2}$ values were detected using an automatic blood gas analyzer (NOVA-K, USA).

\section{Lung water content}

Wet lung weight was determined just after the lung tissue was extracted. After baking at $80^{\circ} \mathrm{C}$ until the weight remained constant, the dry weight of lung tissue was determined. Lung water content was calculated as the ratio of dry weight to wet weight.

\section{Protein content in BALF detection}

Protein content in the BALF was determined using the bicinchoninic acid assay following the manufacturer protocol. Specifically, standard substance bovine serum albumin was diluted and the detection liquid was prepared by mixing reagent $\mathrm{A}$ and reagent $\mathrm{B}$ (50:1). Working solution $(200 \mathrm{~mL})$ with $25 \mathrm{~mL}$ diluted standard substance or sample was added to a 96-well plate in triplicate. After incubation at $37^{\circ} \mathrm{C}$ for $30 \mathrm{~min}$, the optical density (OD) values were determined at $562 \mathrm{~nm}$.

\section{Neutrophil and lymphocytes detection in BALF}

BALF was centrifuged and the sediment was resuspended in $100 \mathrm{~mL}$ saline. Then, the sample was smeared after centrifugation and stained with Giemsa. The numbers of neutrophils and lymphocytes were calculated under a light microscope.

Genetics and Molecular Research 15 (3): gmr.15037265 


\section{Lung tissue hematoxylin and eosin staining}

Lung tissue slices were stained using a process of dewaxing, debenzolization, dyeing, dehydration, transparentation, sealing, and fixation (Gridley et al., 2015).

\section{Enzyme-linked immunosorbent assay (ELISA)}

ICAM-1 and MIP-2 ELISA kits were purchased from Shanghai FMGBio. Serum ICAM-1 and MIP-2 expression levels were detected according to the manual. The procedure was performed as follows. The diluted standard product $(100 \mathrm{~mL})$ was used to prepare the standard curve. Then, $100 \mathrm{~mL}$ sample was added to the wells in triplicate. After washing the plate 4 times, $100 \mathrm{~mL}$ enzyme reagent was added. The plate was washed 4 times again after incubation at $37^{\circ} \mathrm{C}$ for $90 \mathrm{~min}$. Enzyme-conjugated working fluid (100 $\mathrm{mL}$ ) was added to the wells, and the plate was incubated at $37^{\circ} \mathrm{C}$ for $30 \mathrm{~min}$. The reaction was terminated after adding $100 \mathrm{~mL}$ of termination liquid. The plate was read at $450 \mathrm{~nm}$ to determine the OD values. The sample concentration was calculated based on the OD values using the standard curve.

\section{RT-PCR}

Total RNA was extracted from lung tissue and reverse transcribed to cDNA according to the manual. The RT-PCR reaction steps were as follows: $95^{\circ} \mathrm{C}$ for 5 min followed by 40 cycles of $95^{\circ} \mathrm{C}$ for $10 \mathrm{~s}$ and $60^{\circ} \mathrm{C}$ for $20 \mathrm{~s}$. The primers used for PCR were ICAM-1, forward, 5'-CTCTGCTCCTGGTCCTGGT-3'; reverse, 5'-CGTGAATGTGATCTCCTTGG-3'; MIP-2, forward, 5'-CCTCAACGGGCAGAATCAAAG-3'; reverse, 5'-CAAGACATGAGAAAGCAT GA-3'; GAPDH, forward, 5'-CGGAGTCAACGGATTTGGTCGTAT-3'; reverse, 5'-AGCCTT CTCCATGGTGGTGAAGAC-3'. Gene expression levels were quantified by electrophoresis.

\section{Statistical analysis}

All statistical analyses were performed using the GraphPad software. Differences between multiple groups were analyzed by one-way ANOVA. $\mathrm{P}<0.05$ was considered statistically significant.

\section{RESULTS}

\section{Arterial blood gases detection}

As shown in Figure 1, the $\mathrm{PaO}_{2}$ levels for $\mathrm{S}, \mathrm{M}, \mathrm{H}$, and $\mathrm{L}$ groups were $97.45 \pm 14.37$, $62.45 \pm 8.51,76.34 \pm 9.06$, and $90.43 \pm 9.11 \mathrm{mmHg}$, respectively. The $\mathrm{PaO}_{2} / \mathrm{FiO}_{2}$ values for groups $\mathrm{S}, \mathrm{M}, \mathrm{H}$, and $\mathrm{L}$ were $485.74 \pm 38.93,329.73 \pm 29.05,380.52 \pm 30.33$, and $433.48 \pm$ $33.72 \mathrm{mmHg}$, respectively. Compared with those in group $\mathrm{S}$, the $\mathrm{PaO}_{2}$ level and the $\mathrm{PaO}_{2} / \mathrm{FiO}_{2}$ value decreased significantly in group $\mathrm{M}(\mathrm{P}<0.05)$. The $\mathrm{PaO}_{2}$ level and the $\mathrm{PaO}_{2} / \mathrm{FiO}_{2}$ value in groups $\mathrm{H}$ and $\mathrm{L}$ were obviously higher than those in group $\mathrm{M}(\mathrm{P}<0.05)$, and they were even higher in group $\mathrm{H}$ than those in group $\mathrm{L}(\mathrm{P}<0.05)$.

Genetics and Molecular Research 15 (3): gmr.15037265 

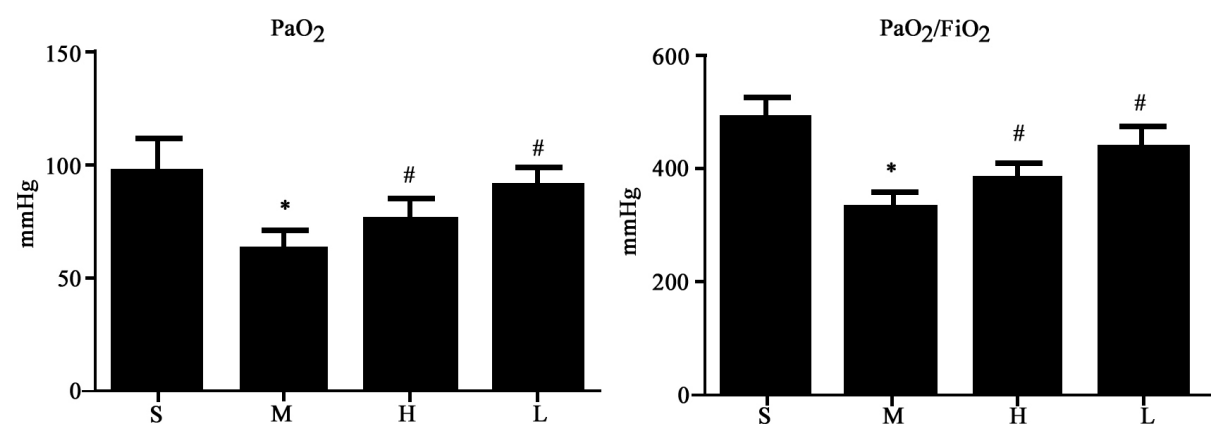

Figure 1. Arterial blood gas detection. ${ }^{*} \mathrm{P}<0.05$, compared with group $\mathrm{S}$. ${ }^{*} \mathrm{P}<0.05$, compared with group $\mathrm{M}$.

\section{Lung water content and protein content in BALF}

As shown in Figure 2, the lung water content in groups $\mathrm{S}, \mathrm{M}, \mathrm{H}$, and $\mathrm{L}$ was $5.18 \pm$ $0.84,7.38 \pm 0.93,6.54 \pm 0.88$, and $5.93 \pm 0.80$, respectively. The protein contents in BALF in groups $\mathrm{S}, \mathrm{M}, \mathrm{H}$, and $\mathrm{L}$ were $59.72 \pm 13.73,215.52 \pm 33.83,169.73 \pm 28.04$, and $120.46 \pm 24.82$ $\mathrm{mg} / \mathrm{mL}$, respectively. The lung water content and the protein content in the BALF increased significantly in group $\mathrm{M}$ compared to those in group $\mathrm{S}(\mathrm{P}<0.05)$. They were markedly lower in groups $\mathrm{L}$ and $\mathrm{H}$ than those in group $\mathrm{M}(\mathrm{P}<0.05)$. Group $\mathrm{L}$ presented obviously lower lung water content and protein content in the BALF than group $\mathrm{H}(\mathrm{P}<0.05)$.
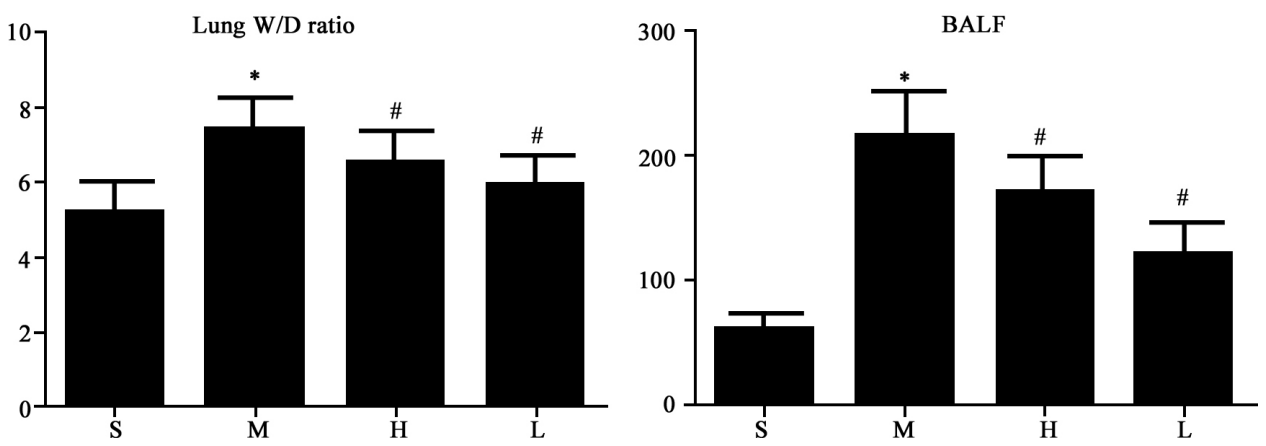

Figure 2. Lung water content and protein content in BALF. ${ }^{*} \mathrm{P}<0.05$, compared with group $\mathrm{S}$. ${ }^{*} \mathrm{P}<0.05$, compared with group $\mathrm{M}$.

\section{Cell count in BALF}

As shown in Figure 3, the neutrophil counts in BALF for groups $\mathrm{S}, \mathrm{M}, \mathrm{H}$, and $\mathrm{L}$ were $(3.84 \pm 0.87) \times 10^{8},(9.03 \pm 0.91) \times 10^{8},(7.53 \pm 0.83) \times 10^{8}$, and $(5.84 \pm 0.89) \times 10^{8}$, respectively. The lymphocyte counts in BALF from groups $\mathrm{S}, \mathrm{M}, \mathrm{H}$, and $\mathrm{L}$ were $(4.14 \pm 0.93)$ x $10^{8},(8.35 \pm 33.83) \times 10^{8},(7.19 \pm 0.84) \times 10^{8}$, and $(5.93 \pm 0.89) \times 10^{8}$, respectively. The neutrophil and lymphocyte numbers in BALF were obviously higher in group $\mathrm{M}$ than those in group $\mathrm{S}(\mathrm{P}<0.01)$. They were markedly lower in groups $\mathrm{L}$ and $\mathrm{H}$ than those in group $\mathrm{M}(\mathrm{P}$ $<0.05)$. Group L showed significantly lower lung water content and protein content in BALF compared to group $\mathrm{H}(\mathrm{P}<0.05)$. 

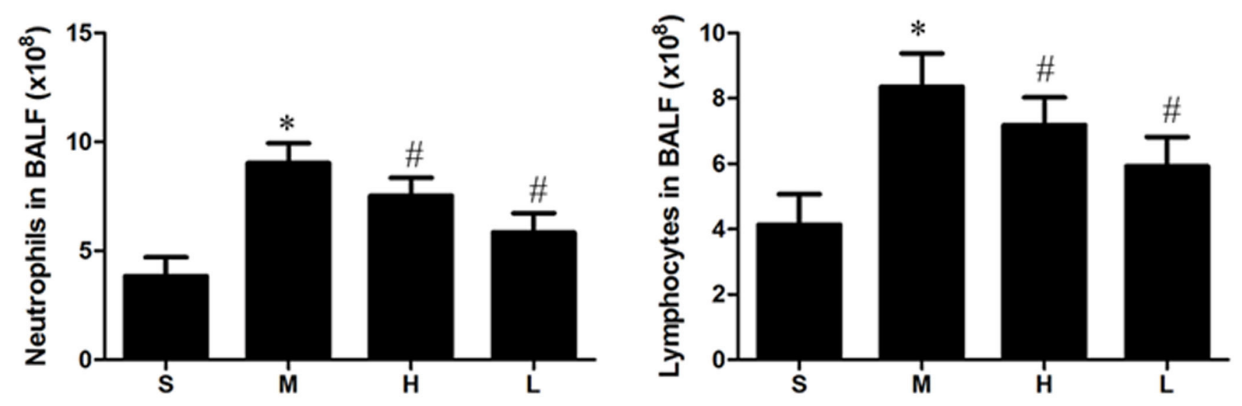

Figure 3. Cell count in BALF. ${ }^{*} \mathrm{P}<0.05$, compared with group $\mathrm{S} .{ }^{*} \mathrm{P}<0.05$, compared with group $\mathrm{M}$.

\section{Morphological examination of lung tissue}

Lung tissue sections from group $M$ showed obvious acute inflammation including interstitial edema and inflammatory cell infiltration. Lung tissue from groups $\mathrm{H}$ and $\mathrm{L}$ presented lighter lesions than those from group $\mathrm{M}$, with marked improvement in group $\mathrm{H}$ compared to those in group L (Figure 4).

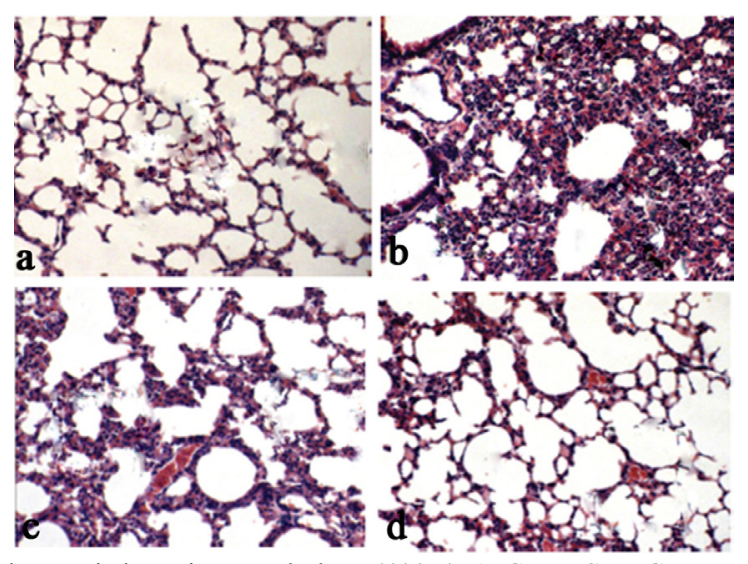

Figure 4. Morphological changes in lung tissue pathology (400X). A. Group S. B. Group M. C. Group L. D. Group H.

\section{Serum ICAM-1 and MIP-2 expression and ICAM-1 and MIP-2 mRNA expression in lung tissue}

As shown in Figure 5, serum ICAM-1 levels in groups S, M, H, and L were $28.93 \pm$ $6.84,138.73 \pm 22.63,100.52 \pm 15.83$, and $60.42 \pm 11.73 \mathrm{pg} / \mathrm{mL}$, respectively. Serum MIP-2 levels in groups $\mathrm{S}, \mathrm{M}, \mathrm{H}$, and $\mathrm{L}$ were $33.73 \pm 8.74,285.74 \pm 33.93,187.94 \pm 22.61$, and 137.52 $\pm 0.89 \mathrm{pg} / \mathrm{mL}$, respectively. Serum ICAM-1 and MIP-2 levels increased significantly in group $\mathrm{M}$ compared to those in group $\mathrm{S}(\mathrm{P}<0.01)$. They were markedly lower in groups $\mathrm{H}$ and $\mathrm{L}$ than those in group $\mathrm{M}(\mathrm{P}<0.05)$, with the lowest expression observed for group $\mathrm{L}(\mathrm{P}<0.05)$. RTPCR revealed that ICAM-1 and MIP-2 mRNA expression in lung tissue was elevated in group $\mathrm{M}$ compared to that in group $\mathrm{S}(\mathrm{P}<0.01)$. Their levels were significantly lower in group $\mathrm{H}$ and $\mathrm{L}$ than those in group $\mathrm{M}(\mathrm{P}<0.05)$, with the lowest expression observed for group $\mathrm{L}(\mathrm{P}<0.05)$. 


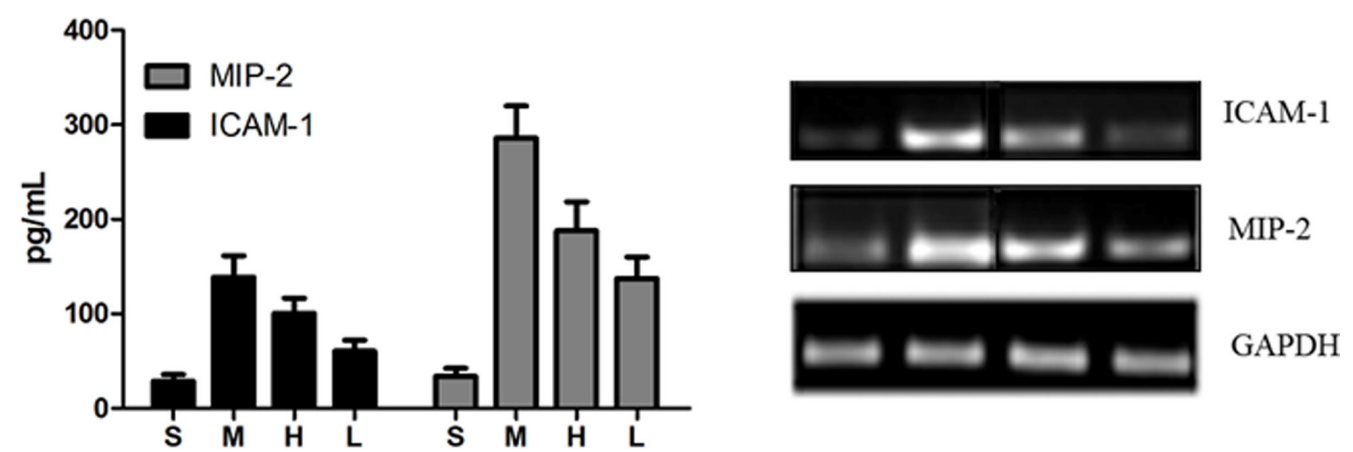

Figure 5. ICAM-1 and MIP-2 expression detection.

\section{DISCUSSION}

At present, ALI and acute respiratory distress syndrome are two types of respiratory diseases with high fatality rates (Maybauer et al., 2006; Tsushima et al., 2009). Sepsis can lead to the development of ALI (Xue et al., 2015). ALI patients exhibit clinical mortality rates of $34-58 \%$, and researchers are searching for new treatment methods for septic ALI. We used the CLP method to establish an ALI rat model with sepsis, and detected the effect of quercetin on arterial blood gases, lung water content, protein content, and cell count in BALF. We further observed the lung tissue pathological morphological changes to test the protective effect of quercetin. Our results revealed that there were many significant differences between the control and model groups $(\mathrm{P}<0.05)$, indicating that the CLP method can be used to successfully derive a sepsis-ALI rat model. Meanwhile, our study found that quercetin treatment can improve ALI markers compared with the model group, and a high dose of quercetin resulted in greater improvement. This treatment effect of quercetin on ALI caused by sepsis is consistent with previous reports (Bai et al., 2014).

However, the mechanism of quercetin in treating septic ALI is still unknown. Quercetin can inhibit colitis progress by suppressing the expression of inducible nitric oxide synthase in a colitis model (Camuesco et al., 2004). Additionally, quercetin can inhibit COPD deterioration by suppressing reactive oxygen and reactive nitrogen generation (Ganesan et al., 2010). It has recently been reported that quercetin can protect against ALI caused by sepsis by regulating NF-kB expression (Bai et al., 2014). However, whether there are other mechanisms involved in the effect of quercetin on septic ALI is unclear. Our research revealed that quercetin can reduce ICAM-1 and MIP-2 levels in both serum and lung tissue, and a high dose of quercetin resulted in an enhanced effect. It has been reported that ICAM-1 is an important adhesion molecule belonging to the immunoglobulin superfamily. ICAM-1 is involved in neutrophil chemotaxis by binding with the surface ligand CD11/CD18 on neutrophils and lymphocytes (Dominguez et al., 2015; Liu et al., 2015; Sumagin and Parkos, 2015). MIP-2 belongs to the chemokine $\mathrm{C}-\mathrm{X}-\mathrm{C}$ subfamily and induces marked chemotaxis in neutrophils and lymphocytes (Takahashi et al., 2009; Tateno et al., 2013; Vagima et al., 2015). ALI occurrence was closely associated with neutrophil and lymphocyte accumulation in lung tissue. Thus, quercetin may play a role in septic ALI protection by regulating ICAM-1 and MIP-2 expression. In summary, our study confirmed that quercetin might protect against ALI in rats with sepsis by suppressing ICAM-1 and MIP-2 expression. 


\section{Conflicts of interest}

The authors declare no conflict of interest.

\section{ACKNOWLEDGMENTS}

We thank the anonymous reviewers for reviewing this manuscript.

\section{REFERENCES}

Ali A, Na M, Svensson MN, Magnusson M, et al. (2015). IL-1 Receptor antagonist treatment aggravates staphylococcal septic arthritis and sepsis in mice. PLoS One 10: e0131645. http://dx.doi.org/10.1371/journal.pone. 0131645

Bai JH, Zhu XY, Zeng LY, et al. (2014). Effect of quercetin on the expression of NF-kB in septic acute lung injury. Progr. Anat. Sci 20: 31-34.

Berthiaume Y, Folkesson HG and Matthay MA (2002). Lung edema clearance: 20 years of progress: invited review: alveolar edema fluid clearance in the injured lung. J. Appl. Physiol. 93: 2207-2213. http://dx.doi.org/10.1152/ japplphysiol.01201.2001

Camuesco D, Comalada M, Rodríguez-Cabezas ME, Nieto A, et al. (2004). The intestinal anti-inflammatory effect of quercitrin is associated with an inhibition in iNOS expression. Br. J. Pharmacol. 143: 908-918. http://dx.doi. org/10.1038/sj.bjp.0705941

Costa MF, de Negreiros CB, Bornstein VU, Valente RH, et al. (2015). Murine IL-17+ Vg4 T lymphocytes accumulate in the lungs and play a protective role during severe sepsis. BMC Immunol. 16: 36. http://dx.doi.org/10.1186/s12865$\underline{015-0098-8}$

Dominguez GA, Anderson NR and Hammer DA (2015). The direction of migration of T-lymphocytes under flow depends upon which adhesion receptors are engaged. Integr Biol (Camb) 7: 345-355. http://dx.doi.org/10.1039/C4IB00201F

Ganesan S, Faris AN, Comstock AT, Chattoraj SS, et al. (2010). Quercetin prevents progression of disease in elastase/ LPS-exposed mice by negatively regulating MMP expression. Respir. Res. 11: 131. http://dx.doi.org/10.1186/14659921-11-131

Gridley DS, Mao XW, Tian J, Cao JD, et al. (2015). Genetic and apoptotic changes in lungs of mice flown on the STS-135 mission in space. In Vivo 29: 423-433.

Krajčinović SS, Doronjski A, Barišić N and Stojanović V (2015). Risk factors for neonatal sepsis and method for reduction of blood culture contamination. Malawi Med. J. 27: 20-24. http://dx.doi.org/10.4314/mmj.v27i1.6

Liu X, Welf ES and Haugh JM (2015). Linking morphodynamics and directional persistence of T lymphocyte migration. J. R. Soc. Interface 12: 12.

Maybauer MO, Maybauer DM and Herndon DN (2006). Incidence and outcomes of acute lung injury. N. Engl. J. Med. 354: 416-417, author reply 416-417. http://dx.doi.org/10.1056/NEJMc053159

Nagarjuna D, Dhanda RS, Gaind R and Yadav M (2015). tcpC as a prospective new virulence marker in blood Escherichia coli isolates from sepsis patients admitted to the intensive care unit. New Microbes New Infect. 7: 28-30. http://dx.doi. org/10.1016/j.nmni.2015.05.002

Odani N, Kitazono H, Deshpande GA and Hiraoka E (2015). Severe sepsis due to otogenic pneumococcal meningitis with pneumocephalus without meningeal symptoms. Intern. Med. 54: 1661-1664. http://dx.doi.org/10.2169/ internalmedicine.54.4074

Sumagin R and Parkos CA (2015). Epithelial adhesion molecules and the regulation of intestinal homeostasis during neutrophil transepithelial migration. Tissue Barriers 3: e969100. http://dx.doi.org/10.4161/21688362.2014.969100

Takahashi K, Koga K, Linge HM, Zhang Y, et al. (2009). Macrophage CD74 contributes to MIF-induced pulmonary inflammation. Respir. Res. 10: 33. http://dx.doi.org/10.1186/1465-9921-10-33

Tateno N, Matsumoto N, Motowaki T, Suzuki K, et al. (2013). Myeloperoxidase deficiency induces MIP-2 production via ERK activation in zymosan-stimulated mouse neutrophils. Free Radic. Res. 47: 376-385. http://dx.doi.org/10.3109 10715762.2013 .778990

Tsushima K, King LS, Aggarwal NR, De Gorordo A, et al. (2009). Acute lung injury review. Intern. Med. 48: 621-630. http://dx.doi.org/10.2169/internalmedicine.48.1741

Vagima Y, Zauberman A, Levy Y, Gur D, et al. (2015). Circumventing Y. pestis virulence by early recruitment of neutrophils to the lungs during pneumonic plague. PLoS Pathog. 11: e1004893. http://dx.doi.org/10.1371/journal. ppat. 1004893

Vincent JL (2014). Assessing cellular responses in sepsis. EBioMedicine 1: 10-11. http://dx.doi.org/10.1016/j. ebiom.2014.10.017

Xue M, Sun Z, Shao M, Yin J, et al. (2015). Diagnostic and prognostic utility of tissue factor for severe sepsis and sepsisinduced acute lung injury. J. Transl. Med. 13: 172. http://dx.doi.org/10.1186/s12967-015-0518-9

Genetics and Molecular Research 15 (3): gmr.15037265 